\title{
SUPORT SYSTEM FOR THE MANAGEMENT OF THE SABANEJEWIA AURATA (DE FILIPPI, 1863) POPULATIONS OF THE ROSCI0227 - SIGHIŞOARA-TÂRNAVA MARE
}

\author{
Doru B $\breve{A N A D U C} *$, Ioana-Cristina CISMAȘ **, \\ Dan MIRICESCU *** and Angela CURTEAN-B $\breve{A N A D U C ~ * * * *}$
}

* "Lucian Blaga” University of Sibiu, Faculty of Sciences, Applied Ecology Research Centre, Dr. Ion Raţiu Street 5-7, Sibiu, Sibiu County, Romania, RO-550012, ad.banaduc@yahoo.com

** "Lucian Blaga" University of Sibiu, Faculty of Sciences, Department of Informatics, Dr. Ion Raţiu Street 5-7, Sibiu, Sibiu County, Romania, RO-550012, cristha_83@yahoo.com

*** "Lucian Blaga" University of Sibiu, Faculty of Engineering, Industrial Engineering and Management Department, Emil Cioran Street 4, Sibiu, Sibiu County, Romania, RO-550025, dan.miricescu@ulbsibiu.ro

**** "Lucian Blaga" University of Sibiu, Faculty of Sciences, Department of Ecology and Environmental Protection, Dr. Ion Raţiu Street 5-7, Sibiu, Sibiu County, Romania, RO-550012, angela.banaduc@ulbsibiu.ro,ad.banaduc@yahoo.com

DOI: 10.1515/trser-2015-0078

KEYWORDS: Natura 2000 network, ROSCI0227 site administration, golden spined loach, Transylvania, Romania.

\section{ABSTRACT}

ADONIS:CE was used to design a computer model for the management of Sabanejewia aurata (De Filippi, 1863) populations in the Natura 2000 site of SighişoaraTârnava Mare (ROSCI0227). The recommended management model is based on the environmental needs of the species, inventoried according to the local habitats, as well as the indicators of conservation status and relevant management measures, and takes into account human pressures and threats identified in the research area. Such computer models were established for all protected fish species found at the site ROSCI0227.

RÉSUMÉ: Un Support Système pour la gestion des populations de Sabanejewia aurata (De Filippi, 1863) du site ROSCI0227 - Sighişoara-Târnava Mare.

ADONIS:CE a été utilisé afin de concevoir un modèle de gestion des populations de Sabanejewia aurata (De Filippi, 1863) du site Natura 2000 Sighişoara-Târnava Mare. Le modèle de gestion recommandé est basé sur les besoins environnementaux de l'espèce, l'inventaire des habitats locaux ainsi que sur les indicateurs de l'état de conservation et sur les mesures de gestion pertinentes, dans un contexte de pressions et de menaces anthropiques identifiées dans la zone de recherche. Des modèles de gestion similaires ont été élaborés pour toutes les espèces de poissons protégées dans le site ROSCI0227.

REZUMAT: Sistem suport pentru managementul populațiilor de Sabanejewia aurata (De Filippi, 1863) din ROSCI0227 - Sighişoara-Târnava Mare.

ADONIS:CE a fost utilizat pentru proiectarea unui model de management al populaţiilor de Sabanejewia aurata (De Filippi, 1863) din situl Natura 2000 Sighişoara Târnava Mare. Modelul de management recomandat se bazează pe nevoile legate de mediu ale acestei specii, inventariate în conexiune cu habitatele locale, pe indicatorii statutului de conservare şi măsurile relevante de management, în contextul presiunilor şi ameninţărilor umane identificate în zona de cercetare. Astfel de modele de management au fost elaborate pentru toate speciile de peşti protejate în ROSCI0227. 


\section{INTRODUCTION}

The EU Habitats Directive was established in 1992 to safeguard the survival of sensitive species in Europe. The signatory countries have to guarantee that the vital conditions are present, for the preservation of the species and habitats listed under Annex 2 of the Habitats Directive, along with the ultimate goal to protect and (if possible) to increase their ecological status. The acceptance of the designated Natura 2000 sites relies upon unambiguous criteria such as: permanent, pristine and healthy fish populations, typical habitats, favourable geographic positioning, and minimal human impact. A few key elements are promoted through the European Union Natura 2000 initiative to improve the condition of nature and protected areas, including: improving specific information; broadening of the protected areas; institutional capacity development; suitable on-the-ground assessment and monitoring; relevant management activities in complex management programs in the areas with conservation status (Bănăduc, 2007; Bănăduc et al., 2012).

The golden spined loach, Sabanejewia aurata (De Filippi, 1863) is a fish species of conservation value. The golden spined loach is a demersal and freshwater species, generally living in the middle and upper sectors of streams and rivers. The presence of sandy riverbeds is a vital habitat quality. The species feeds predominantly on macroinvertebrates (Bănărescu, 1964; Bănărescu and Bănăduc, 2007).

Fish species assemblages in areas where Sabanejewia aurata are found in the Sighişoara-Târnava Mare Natura 2000 site indicates a diminishing population as a result of human impact. The reduction in the area inhabited by this species and their low relative abundance highlights the diminishing natural condition of the Târnava Watershed (CurteanBănăduc et al., 2005; Bănăduc et al., 2016). This reflects a wider global deterioration in water quality and river and stream habitat globally as a result of human-induced pressures (CurteanBănăduc and Bănăduc, 2012).

River habitats are complex and unique, and generic management schemes for protected areas tend not to be satisfactory. Ideally, the main habitat components of each site should be assessed at the beginning of any management process, and any generic scheme adjusted accordingly to support specific species and habitats present at that site.

In conservation, modelling processes are mainly used to get a "large-scale picture" of separate systems and/or actions of definite domains. The parts of the process are helpful in discriminating the different stages of efficient species and habitat management. Using software products such as ADONIS:CE, models can be created that help organisations o understand their protected area management tasks in an easy-to-use way. Models focus on three areas of operation, all important for protected area managers: 1) to validate the current state, 2) to assess the results of modifications and 3) to suggest a program to modify the actual state in a desired manner. In the end, a variety of diagrams can be generated to display specific management elements (Hall and Harmon, 2005).

This research paper aims to: highlight the present state of Sabanejewia aurata populations in Sighişoara-Târnava Mare Natura 2000 site; emphasize human pressures and threats at the site; and use a specially created management model to devise management recommendations to support the rehabilitation of the studied fish species and improve its conservation status. The model integrates habitat preconditions and habitat indicators as a management system for the decision makers. 


\section{MATERIAL AND METHODS}

The Sighişoara-Târnava Mare Natura 2000 site (ROSCI0227) is located in central Romania, in the counties of Brașov, Sibiu and Mureș (85,815 ha, 315-829 m a.s.l.; latitude E 2449'16”, longitude N 468' $\left.4^{\prime \prime}\right)$. This site was designated as a Natura 2000 site for a few fish species which belong to the Annex 2 of the Habitats Directive (92/43/EEC), including: Sabanejewia aurata Natura 2000 code 1146; Barbus meridionalis code 1138, Gobio kessleri/Romanogobio kesslerii code 2511, and Gobio uranoscopus code 1122. (*) Natura 2000 Standard data from http://natura2000.mmediu.ro/upl//formulare/ROSCI0227\%20\%20F.pdf.

The sampling locations where Sabanejewia aurata were sampled are displayed below in figure 1. The samples were taken during 2010-2013, using fishing nets to capture individuals. The individuals were freed after an in situ identification in their natural habitat.

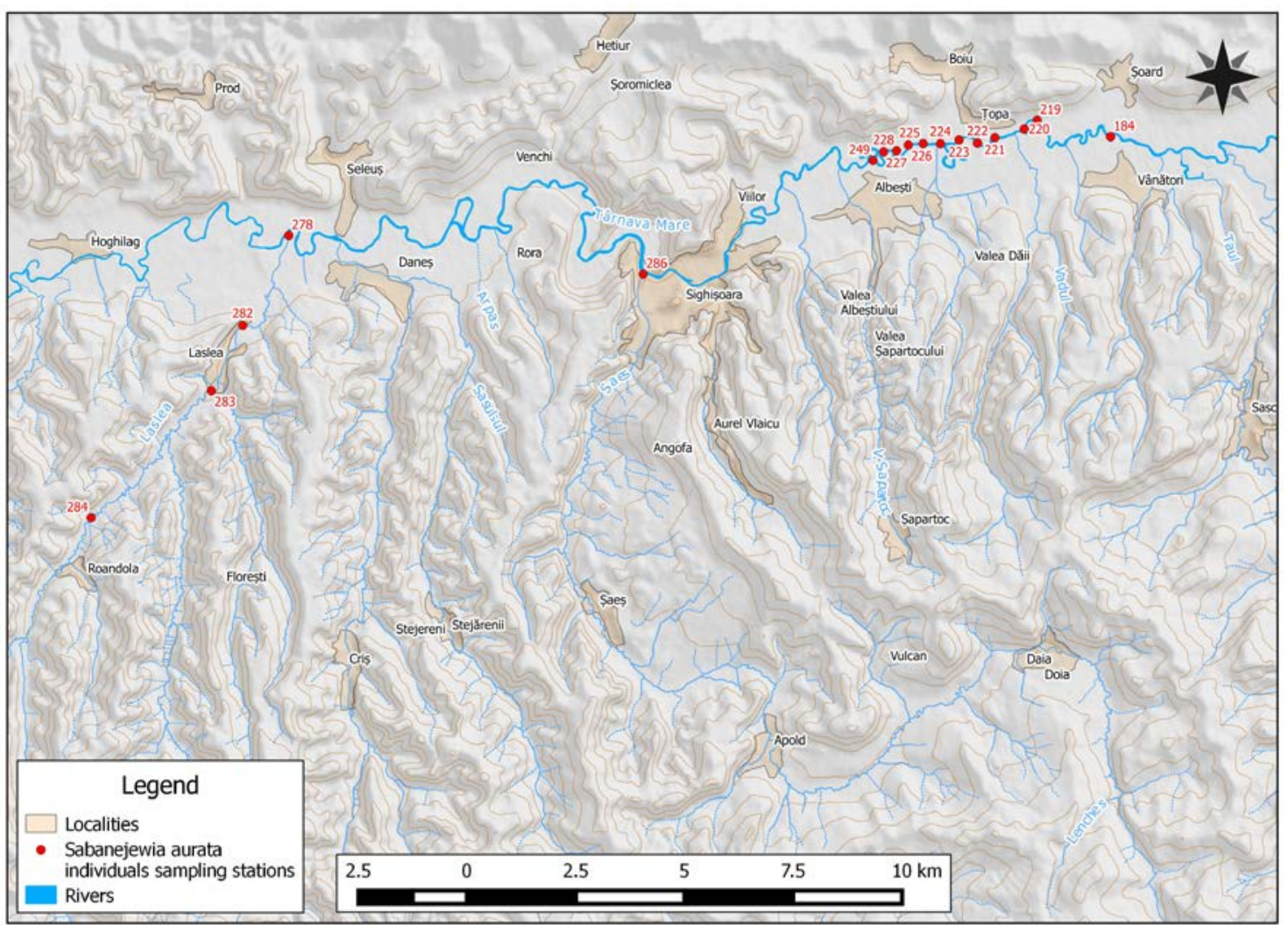

Figure 1: Sabanejewia aurata individual sampling stations in: Târnava Mare River (184, 219, 220, 221, 222, 223, 224, 225, 226, 227, 228, and 249);

Șaeș Stream (286); Laslea Stream (278, 282, 283, and 284),

(Geographic Information System support Mr. Pătrulescu A.). 
The evaluation and ecological situation of Sabanejewia aurata was assessed in relation to the identified human activities, pressures and threats that the natural habitats and population face.

The habitat characteristics of the fish populations were evaluated using specific criteria including: population size, size of range, the equilibrated allocation of fish in age classes, and high/low number of individual fish species in the local fish assemblages.

The habitat needs, pressures, and threats of Sabanejewia aurata were studied in connection with their ecological status, the interrelations between them and the conservation circumstance of Sabanejewia aurata.

An adaptable and flexible management model was recommended to develop a fitting management plan that would effectively preserve the fish species that are living in the research area, with an emphasis on necessary processes. The software ADONIS:Community Edition (ADONIS:CE), a free software designated and offered by the Business Object Consulting (BOC) Group, was used. ADONIS:CE is an easy, stand-alone form of ADONIS with some limitations (in comparison with the commercial version). It uses a Business Process Model and Notation (BPMN), a standardized modelling language which assists in making clear distinct processes. ADONIS:CE is typically used as an access point to Business Process Management. These processes can be modelled using compatible notation.

\section{RESULTS AND DISCUSSION}

\section{Ecological status assessment of Sabanejewia aurata populations}

The ecological status of Sabanejewia aurata in the Târnava Mare River sampling sections (Fig. 1) ranges from very good to low. Very good status was found in sections 227 and 228 sections, good status in 249 and 220, and low status in 184, 219, 221, 222, 223, 224, 225, and 226. This matches the degree of habitat degradation in each section.

The ecological status of Sabanejewia aurata in the Șaeș Stream sampling stations is low (section), and the habitat is in an average/low condition.

The ecological status of Sabanejewia aurata in the Laslea Stream varies between good in sections 278, 284, and 283 and low in the section 282, again matching the quality of habitat in each location.

\section{Human pressures and threats}

This study reveals the fact that the principal pressures on Sabanejewia aurata are: lotic habitat changes in lentic habitats, water chemical pollution, and poaching.

\section{Specific requirements}

In most cases, Sabanejewia aurata lives in lotic sectors with a medium water flow speed, a riverbed composed, at least on the surface, of sand mixed with pebbles or pure sand and riparian ligneous plants. Breeding takes place between May-July. Both the juveniles and adults are easily affected by pollution. (Bănărescu, 1964; Bănărescu and Bănăduc, 2007)

\section{Specific habitat indicators}

In the studied habitats, two main habitat indicators are proposed as explanation for the presence/absence and relative abundance of Sabanejewia aurata: medium water flowing surface speed, proportion (50\%) combined with sandy-pebbles (33\%) or sandy riverbed surface proportion (33\%), and river banks with riparian vegetation proportion (50\%). 


\section{Management measures}

Management measures have been, for a long time, the goal for theoretical study, as well as management specialists. Consequently there is a range of alternative approaches and models which vary based on origin, measurement systems and complexity. The management indicators can be developed within a process made up of six steps which are represented in figure 2, based on the Mertins and Krause affirmations (Mertins et al., 1999).

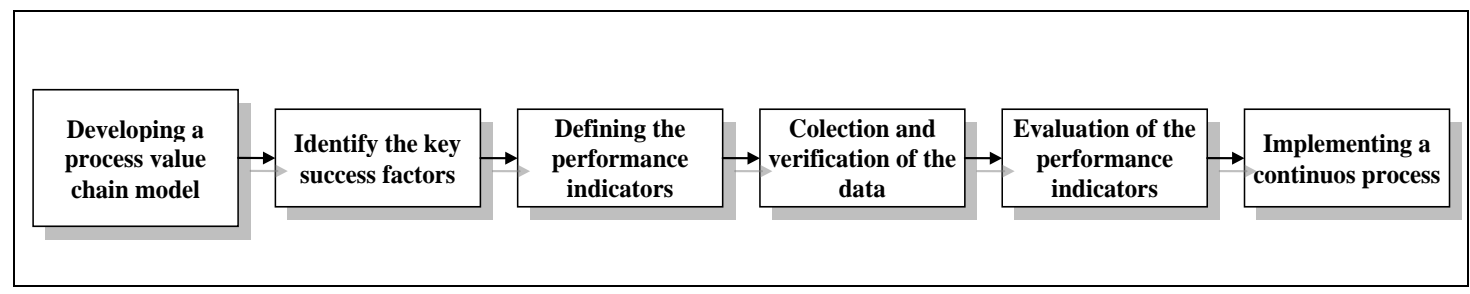

Figure 2: Stages for building an indicator set in the Fraunhofer Approach.

The points of this approach are: it is based on a fundamental model; it is assisted by the learning process which happens while drawing up the process maps; and it identifies the need for management measures planning built around the record sheets of management measures. Therefore it is important to emphasize that starting from the idea and need to identify an indicator set for assessing an entity's overall performance, the presented model identifies the main value delivery process, to which an indicator set for process assessment can be assigned, which are determined by identifying the key success factors, for the process itself but also for the entity's global performance (Miricescu, 2011, 2014).

Krahn $(1998,2001)$ proposes the following reference model for a systematic definition of indicators and for building a solid Process Monitoring System (PMS) (Fig. 3). PMS has evolved from process management concepts, comprising design, control and development of business processes.

\begin{tabular}{|l|ll|}
\hline Objectives & \multicolumn{1}{|c|}{ Retrieving and measuring process quality } \\
\hline \hline Features & $\bullet \quad$ Obtaining an integrative view and an overview of the process. \\
& $\bullet \quad$ Serious process coordination. \\
& $\bullet \quad$ Objective support - oriented improvement process. \\
& $\bullet \quad$ Comparability of process quality. \\
& $\bullet \quad$ Performance oriented incentive scheme. \\
\hline
\end{tabular}

Figure 3: Objectives and features for the Process Monitoring System (PMS) (Krahn, 1998).

The right determination of process quality depends on the definitions given by the indicators. The reference model is fixed on a hierarchical system of indicators. The three levels are: 1. Indicators for process coordination - this refers to the entity's objectives and involves the process quality in relation to long-term objectives. These are provided for strategic decisions for guidance, purpose and structure of the process. 2. Indicators proper to the process - these are applied to the actual objectives of the project. They ensure the recognition of process potential. 3. Performance indicators for the process - these take into account the objectives of a single activity from the process. The operational potential is determined by these factors. 
The reference model will be based on all these three architectural levels, following a particular procedure with three sequential phases.

Phase 1: Defining the objectives. Objectives are determined at the level of the entity, the process and the activity.

Phase 2: Defining the success factors. The critical success factors are, according to Rockart (1979) "the limited number of areas in which the results will ensure successful performances". This statement is applied in the Process Monitoring System (PMS). The critical success factors are identified on each level (Mende, 1995).

- $\quad$ Generic success factors

- $\quad$ Procedural success factors

- $\quad$ Specific success factors

This phase ends by pinpoint the success factors for the important activities of the process.

Phase 3: Defining the indicators). To ensure the success of a procedure from top to bottom, the definition of the indicators begins at the process coordination level. The success objectives and factors carried by the analysed process must be established. The chosen indicators must reflect the achievement of these objectives and factors over the course of the project. The measurements and results mirrored by the indicators will show how the entity's objectives are accomplished by the analysis process. These measurement units have to meet the measurement necessities for the processes objectives and for the success factors.

In line with this model we consider that the main management measures for this specific case study are: preservation of the natural morphology of the lotic systems and their banks, a ban on the disposing of any type of waste in streams and rivers, control of the pollution and mineral overexploitation of the riverbeds, and the creation of a monitoring system for ichthyofauna conducted by qualified/specialised personnel.

Any hydrotechnical work that will significantly diminish the river water flow of some lotic systems will decrease the number of individuals for this species to the point of local extinction, so creation of lentic areas are not recommended. In this regard, it is strongly recommended that any bridge construction, culverts, or any other modifications of the water speed regime are to be performed during the maximum multiannual levels, so that the impact would be as low as possible.

In all river sectors, the illegal phenomenon of poaching is quasi-permanent and intense and requires more efficient control.

It is necessary to prohibit the abandonment of any kind of waste in the river bed and surrounding wetlands of watercourses.

Seasonal integrated monitoring is recommended. This should include the monitoring of water charging elements with organic substances.

In the Şaeş and Laslea streams, a continuous water flow must be provided, namely reducing the flow takeover during dry periods. On the same streams, the effects of organic and chemical pollution should to be reduced. 


\section{Adjusted model for the site management}

In this paper, an overview image of ecological requirements of Sabanejewia aurata species was tried on a section of the Sighișoara-Târnava Mare Natura 2000 site. To create this management model we used ADONIS:CE, a tool for modelling business processes, which has been used to view this species' management measures that need to be taken in order to preserve favourable conservation status. For this model, the following modelling objects were used: activities (blue rectangles), describing species characteristics (green ovals), decisions (yellow diamonds). These check the current state of each indicator compared to favourable conservation status, parallelism and merging objects by describing the activities that occur at the same time, variables and generators that help in determining the percentage of achievement of each indicator in hand.

Model description (Fig. 4): The model starts with a suite of seven activities that describe the scientific name of the species and common names, the critical requirements of habitat - including detailed habitat types - what the species needs for reproduction, shelter and food, possible indicators, and lastly presents the current state of indicators (measured on the ground) compared to favourable conservation status. When all of these requirements (specific and critical), have been described, by making use of decisions, the four indicators are checked (sandy substrates, gravel substrates, surface covered with water and riparian vegetation sides), to see if the values measured in the field comply with favourable conservation status.

If all indicators comply with favourable conservation status, then continue with the activity of creating a monitoring system conducted by trained personnel in this field and check again whether the conservation status is favourable. If so, then the model is continued by six activities - filling in a species sheet - describing observations in the field, other ecological requirements, current pressures, threats, reproduction and distribution in the protected area and the model ends. If it does not fulfil favourable conservation status, then return to activity. Repeat the model until the actual state versus the favourable conservation state match, and every indicator suggests a favourable conservation status.

Given that possible indicators listed above do not fulfil the conservation of the species, then using parallelism and merging objects, management measures are presented to be followed by activities that take place at the same time. In the case of this species, regardless of which indicator is checked the same management measures in the form of three activities have to be taken: preserving the natural morphology of the lotic systems and their banks, banning pollution and the disposal of any type of waste in the rivers and streams, and controlling mineral overexploitation of the riverbeds. The modelling process continues with the activity of implementing a monitoring system to verify whether the conservation status is favourable, and if so, as described above, follows six activities with completions of species sheet. If not, the process forms a loop and returns to activity. Actual state versus the favourable conservation state will go again through possible indicators related to decisions.

Figures 4 and 5 show different paths that follows the process if they choose branch "YES" to the first indicator (decision: "Current state of sandy substrate weight is 33\%?" probability: 90\% for "YES" branch, 10\% for "NO" branch) the "NO" branch of the second indicator (decision: "The current state of gravel substrate weight is 33\%?" probability: $33 \%$ for "YES" branch and 67\% for "NO" branch), and "YES" branch if the decision is in favourable conservation status (probability 75\% for "YES" branch and 25\% for "NO" branch) - the path is shown by the thickening border of process objects. 


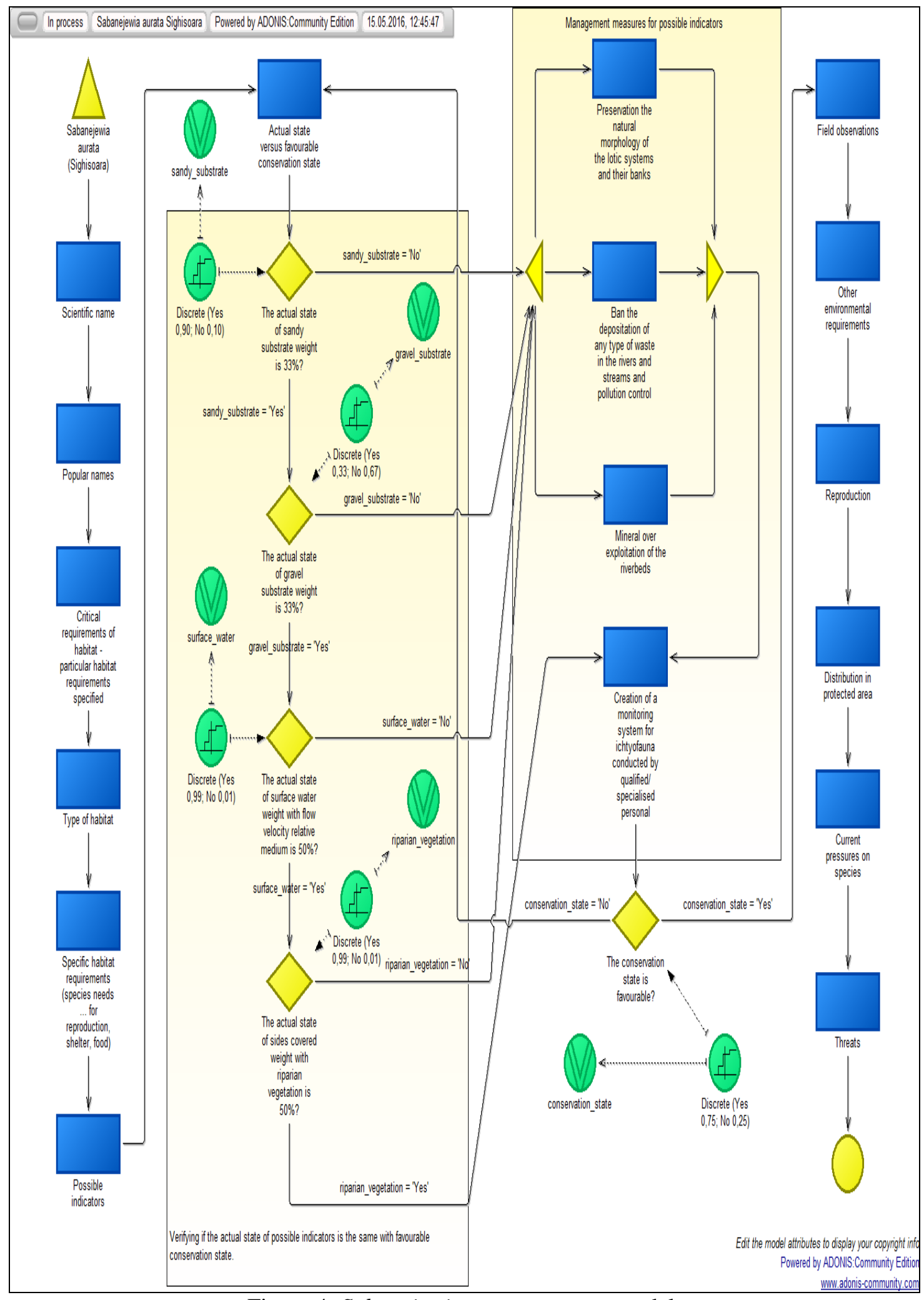

Figure 4: Sabanejewia aurata process model. 


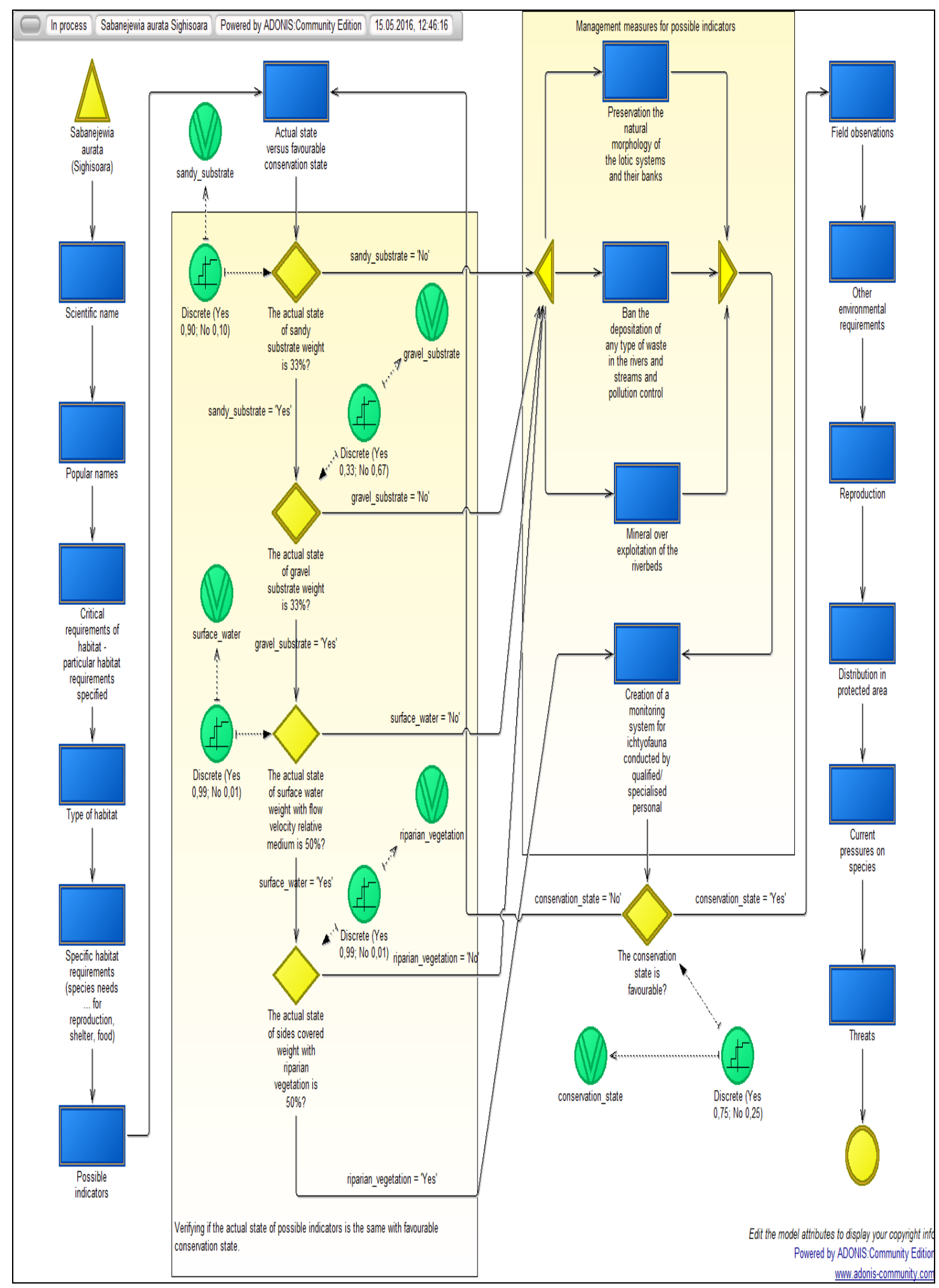

Figure 5: Process animation for Sabanejewia aurata species. 


\section{CONCLUSIONS}

The main pressures preventing the golden spiny loach, Sabanejewia aurata, from having a good conservation status and healthy populations in the studied site are: changing the lotic habitats into lentic ones, and suppressing water chemical pollution and poaching.

Significant elements that need to be solved for the conservation of Sabanejewia aurata are as follows: conservation of the natural morphology of the streams, rivers and their banks, banning the disposal of any category of waste in the river and stream areas, pollution management, preventing mineral overexploitation of the riverbeds, and the establishment of a monitoring system for ichthyofauna conducted by qualified/specialised personnel.

In this study, a targeted management model designed to sustain the populations of Sabanejewia aurata in Sighişoara-Târnava Mare Natura 2000 site was developed using ADONIS:CE.

The ADONIS:CE was applied here in the nature protection framework, illustrating a management model of Sabanejewia aurata that circumscribes its necessities in relation to the habitat, the indicators that characterize a good ecological status, and the relevant management actions needed to prevent and/or remove the pressures and threats which influence these fish populations.

If the suggested management elements are put into action, Sabanejewia aurata will have a decreasing trend in the next 12-30 years in the studied area.

This particular on-site, on-habitats and on-species management model for Sabanejewia aurata, must be assimilated in an integrated management model for the Sighişoara-Târnava Mare Natura 2000 site ichthyofauna.

\section{REFERENCES}

1. Bănăduc D., 2007 - Middle Olt River (Transylvania, Romania) - Special area for conservation (Natura 2000 Site) proposal for Cobitis taenia Risso, 1827 and associated fish species, Acta Ichtiologica Romanica, II, 37-42.

2. Bănăduc D., Nagy A. and Curtean-Bănăduc A., 2012 - New SCIS proposal regarding the ichthyofauna after the Continental Biogeographic Seminar for Romania, Sibiu (Transylvania, Romania), 9-12 June 2008, Acta Oecologica Carpatica, V, 145-158.

3. Bănărescu P. M., 1964 - Pisces-Osteichthyes, Fauna R. P. R., XIII, Edit. Academiei Republicii Populare România, Bucureşti, 962. (in Romanian)

4. Bănărescu P. M. and Bănăduc D., 2007 - Habitats Directive (92/43/EEC) fish species (Osteichthyes) on the Romanian Territory, Acta Ichtiologica Romanica, II, 43-78.

5. Curtean-Bănăduc A. and Bănăduc D., 2012 - Aspecte privind impactul deversării apelor uzate asupra sistemelor ecologice lotice receptoare, II, coordonator Oprean L., Edit. Academiei Române, 393-416. (in Romanian)

6. Hall C. and Harmon P., 2005 - The Enterprise Architecture, Process Modeling and Simulation Tools Report, Version 1.1 (2005) November.

7. Krahn A., 1998 - Indikatoren für ein Prozeß - Monitoring, Information Management, 4, 57-63.

8. Krause O. and Mertins K., 1999 - Performance management, in Mertins K., Krause O., and Schallock O., Global Production Management, Proceedings of the IFIP, WG5.7 International Conference on Advances in Production Management Systems, September, 243-251.

9. Mende M., 1995 - Ein Führungssystem für Geschäftsprozesse, St. Gallen, 150-160.

10. Miricescu D., 2011 - Study on temporal influences on management and managers of business organizations, Proceedings of RMEE, Todesco Publising House, 479-490.

11. Miricescu D., 2014 - Semnele şi amprenta timpului asupra managementului contemporan, Edit. Universităţii “Lucian Blaga” din Sibiu, Sibiu, 69-88. (in Romanian)

12. Rockart J. F., 1979 - Chief executives define their own data needs, Harvard Business Review, 2, 81-92. 